\title{
IZAZOVI PARTNERSTVA U USTANOVAMA RANOGA I PREDŠKOLSKOGA ODGOJA I OBRAZOVANJA U VRIJEME PANDEMIJE KORONAVIRUSA
}

\author{
CHALLENGES OF PARTNERSHIPS IN EARLY \\ CHILDHOOD AND PRESCHOOL EDUCATION \\ INSTITUTIONS DURING THE COVID-19 PANDEMIC
}

\author{
ANKA JURČEVIĆ LOZANČIĆ ${ }^{1}$, JASNA KUDEK MIROŠEVIĆ ${ }^{1}$ \\ ${ }^{1}$ Sveučilište u Zagrebu, Učiteljski fakultet, Savska 77, Zagreb, Hrvatska, kontakt: slanovecka@gmail.com
}

Primljeno/Received: 06.01.2021.

Prihvaćeno/Accepted: 24.03.2021.

Sažetak: Postojeće životne situacije izazvane globalnom pandemijom bolesti COVID-19 krizni su i uznemirujući događaji koji mijenjaju obiteljski život. Stoga je važno pružiti podršku obiteljima u ispunjavanju njihove odgojne funkcije, ostvarivati kontinuiranu komunikaciju i dijalog te osmisliti smjernice i strategije za međusobnim povezivanjem, zajedničkim sudjelovanjem djece $i$ odraslih u različitim životnim aktivnostima. Posebnu pozornost potrebno je usmjeriti na obitelji djece koja imaju posebne odgojno-obrazovne potrebe. Svaka obitelj, bez obzira na postojeće sposobnosti i mogućnosti djeteta, želi da njihovo dijete bude prihvaćeno i uključeno u zajednicu $i$ u kvalitetne programe kako bi se djetetu osiguralo poticajno okruženje i materijali za aktivno učenje i kvalitetan razvoj, kako se ne bi povećavali dodatni izazovi s kojima se obitelji suočavaju tijekom pandemije. S obzirom na manji broj istraživanja o korelatima učinkovite suradnje odgojitelja u vrijeme bolesti COVID-19, posebice u našem okruženju, cilj je ovoga istraživanja ispitati jesu li određene sociodemografske značajke odgojitelja (godine radnoga iskustva i stručna sprema) povezane s određenim aspektima kvalitete partnerske suradnje u ustanovama ranoga i predškolskoga odgoja i obrazovanja u vrijeme pandemije koronavirusa. Za potrebe istraživanja konstruiran je Upitnik o kvaliteti partnerske suradnje odgojitelja i roditelja $u$ vrijeme izvanrednih životnih okolnosti izazvanih pandemijom bolesti COVID-19 koji je proveden na uzorku od 313 odgojitelja. Izračunata je korelacija između samoprocjene partnerske suradnje i godina radnoga iskustva te stručne spreme odgojitelja, dok je analiza varijance korištena za testiranje razlika u procjeni nekih aspekata suradnje s obzirom na radno iskustvo odgojitelja. Rezultati provedenoga istraživanja
Izvorni znanstveni rad/Original research article UDK: 373.2:616-036.21 doi: https://doi.org/10.31299/hrri.57.1.7

\begin{abstract}
The current living circumstances caused by the global COVID-19 pandemic are considered to be deeply disturbing as they have resulted in significant changes in the lives of families around the globe. Special attention needs to be directed towards families with children with special educational needs. Since there are relatively few studies analysing the coherence of effective cooperation with educators during the pandemic, especially in our surroundings, this study aimed to examine whether certain sociodemographic characteristics of educators (years of work experience and professional qualifications) are related to specific aspects of the quality of partnerships and cooperation in early childhood and preschool education institutions during the pandemic. For the purpose of this study, a Questionnaire on the quality of partnerships between educators and parents during the out-of-the-ordinary life circumstances caused by the Covid-19 pandemic was developed and distributed to 313 educators. Correlation coefficients were calculated to test the relationship between the educators'self-assessment of their partnerships and cooperation with parents and their work experience (in years), as well as their professional qualifications. Analysis of variance was used to test the differences in the assessment of some aspects of cooperation with regards to the work experience of the educators. The results show that educators assess their partnerships with parents during the pandemic as being of high quality and perceive themselves as competent in building partnerships with parents of all children, as well as in providing support to parents of children with disabilities. Educators with more years of work experience consider themselves as less competent in using digital technology and believe that they
\end{abstract}


Hrvatska revija za rehabilitacijska istraživanja 2021, Vol 57, br. 1, str. 128-144

pokazuju kako odgojitelji partnersku suradnju s roditeljima $u$ vrijeme pandemije koronavirusa procjenjuju kvalitetnom te se smatraju kompetentnima u izgradnji partnerskih odnosa s roditeljima, kao i u pružanju podrške roditeljima djece s teškoćama. Odgojitelji s više godina radnoga iskustva smatraju se manje kompetentnima u korištenju digitalne tehnologije te smatraju kako im u tom aspektu treba više teorijskoga usavršavanja i praktičnoga iskustva.

Ključne riječi: dijete rane i predškolske dobi, partnerstvo obitelji i predškolske odgojno-obrazovne ustanove, sociodemografske odrednice, socijalna povezanost

\section{UVOD}

Danas djeca odrastaju u obiteljima koje su različito tehnološki kompetentne. Neki roditelji primjerice nemaju znanja i mogućnosti koristiti digitalne tehnologije, imaju niže obrazovanje ili ograničene materijalne resurse. Unatoč navedenim (i mnogim drugim okolnostima) ostvaruju pravo na podršku u svojoj zajednici, tj. na kvalitetan i osmišljen odgoj i obrazovanje. U izvanrednim situacijama fizičkoga distanciranja, povremene ili stalne izolacije, izazvanim globalnom pandemijom koronavirusa, uloga je odgojitelja da iniciraju povezanost djece, roditelja i odgojitelja $u$ obiteljskim uvjetima. Konkretnije: “(...) roditelji i djeca imaju svoje snove, želje, očekivanja i nade, ponekad nedefinirano pozicionirane duboko u njihovim mislima i srcima, stoga se od odgojitelja očekuje da razvijaju i unapređuju praksu partnerstva koristeći otvorenu komunikaciju i dijalog" (Curtis i Carter, 2008, str. 49). Spomenuti autori naglašavaju važnost strukturiranih, stabilnih i predvidivih svakodnevnih aktivnosti u ustanovama ranoga odgoja i obiteljima koje pridonose pozitivnom razvoju djece, ali i otpornosti obitelji. Kompetencije odgojitelja potrebne za kvalitetnu praksu partnerstva i profesionalno djelovanje podrazumijevaju njegovu osjetljivost za potrebe djece i roditelja kao i iniciranje pedagoških aktivnosti u skladu s navedenim. Osobito relevantno za razvoj partnerstva jest preispitivanje odnosa $\mathrm{s}$ roditeljima djece s teškoćama te je potrebno naglasiti važnost inkluzivnosti koja podrazumijeva uvažavanje različitosti, dostupnost, otvorenost i participaciju djece, roditelja i odgojitelja (Jurčević Lozančić i Golik Homolak, 2020). need more theoretical knowledge and practical experience in this aspect.

Keywords: early childhood; preschool education; partnership; family; educators; sociodemographic determinants; social connection

\section{INTRODUCTION}

Nowadays, children grow up in families with diverse technological competencies. For example, some parents do not possess the knowledge or ability to use digital technology, have lower levels of education, or limited material resources. Despite the aforementioned difficulties (and many others), they reserve the right to gain support from their communities, i.e., to obtain a quality, carefully planned education for their children. In these exceptional circumstances of physical distancing, as well as temporary or permanent isolation caused by the global COVID-19 pandemic, the role of the educator (the term 'educator' refers to early childhood and preschool teachers) is to initiate social connection between children, parents, and educators in familial conditions. To be more precise, "parents and children have their own dreams, wishes, expectations and hopes, that are sometimes positioned deeply in their thoughts and hearts, which is why the educators are expected to develop and improve the practice of partnership using open communication and dialogue" (Curtis and Carter, 2008, p. 49). The authors also emphasise the importance of structured, stable, and predictable everyday activities in early childhood educational institutions and families that contribute to the positive development of children, as well as to the resilience of families. The educator's competency is necessary for quality partnerships and their professional impact is often based on their sensitivity to the needs of the children and parents, as well as on initiating pedagogical activities in accordance with everything mentioned thus far. Thinking about relationships with parents of children with disabilities is especially relevant for the development of 
Odgojno-obrazovna inkluzija razvija se i uči, oblikuje ritam zajedništva, zrcali osobnost odgojitelja, međusobnu socijalnu povezanost djece, reflektira njihove načine zajedničkoga života i učenja. Navedeni pristup prepoznaje se u odgojno-obrazovnim ustanovama koje njeguju kulturu bogatoga partnerstva i koja se temelji na kvalitetnim odnosima, a ne na strukturiranim pravilima (Curtis i Carter, 2008). Iz tih se razloga sve više ističe važnost učenja onoga što će djeci koristiti u životu te se usmjerava pažnja prema socioemocionalnim čimbenicima u procesu učenja i razvoja djece (Igrić i sur., 2015).

Jedna je od temeljnih zadaća obitelji da na različite načine strukturira svoj život kako bi se osigurao razvoj i dobrobit njezinih članova, odnosno da omogući djeci integriranje materijalnih i kulturnih vrijednosti te dnevnih aktivnosti. Prema Čudina-Obradović i Obradović (2006) obitelji koje pružaju dovoljno strukture, stabilnosti i predvidljivosti u smislu dnevnih rutina, obiteljskih pravila te obiteljskih rituala osiguravaju potrebne resurse za socijalizaciju djece i dobrobit njezinih članova. Time se želi naglasiti da se djeca koja imaju povoljnije obiteljsko okruženje mogu bolje prilagoditi kriznim i uznemirujućim događajima. Ako navedene spoznaje promatramo u svjetlu vremena obilježenoga globalnom pandemijom koja mijenja život obitelji, od odgojitelja se očekuje da pomogne roditeljima pri kreiranju poticajne okoline za dijete. Izazovi koje djeca s posebnim odgojno-obrazovnim potrebama čine zbog svojih različitosti ne smiju rezultirati pasivnošću odraslih. Jer svako dijete ima svoje vrijednosti, vještine, znanje, strasti i interese za igrom i učenjem (Thompson, 2015).

Prema Nenadić Bilan (2014) bitno obilježje obiteljskog konteksta koje je u funkciji zadovoljavanja vitalnih potreba djece jest roditeljska uključenost koja podrazumijeva njegu, razvoj i odgoj djeteta, kao i zajedničke aktivnosti s djecom, posebice u igrama. Rezultati istraživanja spomenute autorice sugeriraju da roditelji trebaju pomoć u organizaciji kvalitetno provedenoga zajedničkoga vremena s djecom, a upravo je igra najprirodniji kontekst za uspostavu prisnih interakcija roditelja i djece. Stoga odgojitelj koji promovira važnost obitelji za razvoj i odgoj dje- partnerships, and it is necessary to emphasise the importance of inclusion, which implies the appreciation of differences, availability, openness, and participation of children, parents, and educators (Jurčević Lozančić and Golik Homolak, 2020). Educational inclusion should be developed in a way that it forms a rhythm of togetherness, mirrors the educator's personality and social relationships of the children, as well as reflects their ways of living and learning together. This approach is recognised in educational institutions that nourish culture of rich partnerships based on quality relationships, and not on structured rules (Curtis and Carter, 2008). Therefore, the importance of learning and understanding factors that will be useful to the children during their lives is greatly emphasised, and the focus moves toward socioemotional factors in the process of learning and development of children (Igrić et al., 2015).

One of the basic tasks of a family is to structure their life in different ways so that the development and welfare of their members is ensured. For example, one task is to provide children with daily activities and the possibility of integrating material and cultural values. Čudina-Obradović and Obradović (2006) observed that families who provide the necessary structure, stability, and predictability in the sense of daily routines, family rules, and rituals also provide the necessary resources for socialisation of their children and the general welfare of all family members. This emphasises that children who have favourable familial surrounding can adapt better to crises and disturbing events. If we consider these findings in the light of a situation that is scarred by the global pandemic that has altered the normal lives of families, educators are expected to help parents create a supportive environment for the children. The challenges that arise with respect to children with special educational needs cannot result in the passivity of adults. Every child has individual values, skills, knowledge, passions, and interests for playing and learning (Thompson, 2015).

According to Nenadić Bilan (2014), an important trait of the familial context that serves the function of satisfying the vital needs of children is parental involvement that implies care, development, and education, as well as participating in the activities with the children, especially during playtime. Parents need help organise quality time with children, since playtime is the most natural context 
teta na adekvatan će način odgovoriti na različite potrebe obitelji u iznenadnim i složenim životnim okolnostima te pridonijeti jačanju roditeljskih kompetencija.

Bogata povijest istraživanja pokazala je kako roditeljstvo utječe na razvoj i ponašanje djeteta. Općenito govoreći, istraživanja su pokazala da roditeljska praksa koja uključuje osiguravanje pozitivnoga potkrepljenja (Fantuzzo, Perry i Childs, 2006; Keyser, 2006; Jackson i Needham, 2014) uključenost u djetetove aktivnosti, kvalitetno provođenje vremena s djetetom (Ljubetić, 2014), participacija u predškolskim aktivnostima i redovita komunikacija roditelja i odgojitelja, utječe na rane dječje ishode (Powell, Son, File i San Juan, 2010; Fantuzzo i sur., 2013; Ward, 2013). Budući da je sudjelovanje obitelji tijekom ranih godina djetetova života povezano s postignućima u daljnjem životu, potrebno je kontinuirano istraživati potrebe $\mathrm{i}$ interese roditelja kao ključnih ili poželjnih partnera, istodobno s jačanjem međusobnih partnerskih odnosa (SoutoManning i Swick, 2006; Jurčević Lozančić, Basta i Šerbetar, 2019). U tom smislu Christenson, Palan i Scullin (2009), Giovacco-Johnson (2009), Kersey i Masterson (2009), Powell i McCauley (2011) te Sammons i sur. (2015) ističu važnost sociokulturnoga pristupa koji zahtijeva od svakog odgojno-obrazovnoga djelatnika da se u suradnji s obitelji suoči sa svim stereotipima, predrasudama i različitostima te da pronađe adekvatne strategije za razvoj partnerstva. Souto-Manning i Swick (2006) te Gartrell (2012) naglašavaju da je odgovornost odgojitelja da istražuju potencijal suradnje s roditeljima, kako bi osnažili roditelje da budu aktivni sudionici u djetetovu odgoju i obrazovanju. Naime uvijek kada djeca promatraju pozitivne interakcije između roditelja i odgojitelja, počinju shvaćati važnost izgradnje zdravih odnosa, što predstavlja krucijalni čimbenik uspjeha inkluzivnoga obrazovanja. Djeca se osjećaju sigurnije s odgojiteljima koje roditelji vidljivo poštuju i vjeruju im, a to im povratno omogućuje da se osjećaju ugodno i zadovoljno. Istraživanje Nitecki (2015) govori o integriranom partnerstvu koje je temeljeno na višedimenzionalnoj prirodi odnosa te autorica naglašava važnost odgojitelja u kreiranju ugodnoga okruženja koje je esencijal- for establishing close interactions between parents and children. Therefore, the educator who promotes the importance of family for the development and education of the child must respond adequately to various needs of families faced with sudden and complex life circumstances, as well as contribute to strengthening the competencies of parents.

A number of previous studies have shown that parenthood affects the development and behaviour of children. Studies have generally shown that parenthood practices that include ensuring positive reinforcement (Fantuzzo, Perry and Childs, 2006; Keyser, 2006; Jackson and Needham, 2014), involvement in children's activities, quality time spent with the child (Ljubetić, 2014), participation in preschool activities, and regular communication between the parents and the educator affects early childhood outcomes (Powell, Son, File and San Juan, 2010; Fantuzzo et al., 2013; Ward, 2013). Given that the involvement of the family during the early years of the child's life is connected with achievements later on in life, it is necessary to continuously research the needs and interests of parents as integral and preferred partners, while strengthening partnership interrelations at the same time (Souto-Manning and Swick, 2006; Jurčević Lozančić, Basta and Šerbetar, 2019). Keeping that in mind, Christenson, Palan and Scullin (2009), Giovacco-Johnson (2009), Kersey and Masterson (2009), Powell and McCauley (2011), and Sammons et al. (2015) emphasised the importance of a sociocultural approach that requires every educator to work in unison with the family in order to confront all stereotypes, judgements, and differences and to find adequate strategies for partnership development. Souto-Manning and Swick (2006), as well as Gartrell (2012), emphasised that the responsibility of the educator is to analyse the potential of cooperating with the parents and to strengthen parents to be active participants in their child's education. When children witness positive interactions between parents and educators, they start to realise the importance of building healthy relationships, which presents a crucial factor in achieving inclusive education. Children feel safer with educators when they see that their parents respect and trust them, which ultimately makes them feel comfortable and satisfied. Nitecki (2015) studied integrated partnerships based on the multidimensional nature of relationships, and 
no za bliske odnose roditelja i odgojitelja, kao i važnost želje i nastojanje odgojitelja za jačanjem partnerstva. Kvalitetna rana i predškolska skrb o djeci pridonosi njihovu emocionalnom, socijalnom i intelektualnom razvoju i predstavlja njihovo učenje. Stoga djeca s teškoćama imaju koristi od kvalitetne rane i predškolske njege i podrške jednako kao i djeca tipičnoga razvoja. U tom smislu odgojitelji za pružanje podrške roditeljima i djeci s teškoćama trebaju biti senzibilizirani, osjećati se kompetentnima i postavljati ciljeve koji će motivirati roditelje na suradnju i partnerstvo koji otvaraju različite mogućnosti za autentično obiteljsko angažiranje.

\section{CILJ I HIPOTEZE ISTRAŽIVANJA}

S obzirom na to da u Republici Hrvatskoj još uvijek nedostaju istraživanja koja se bave proučavanjem kvalitete partnerstva u vrijeme pandemije koronavirusa iz pedagogijske perspektive, što je bio poticaj za provedbu ovoga istraživanja, cilj je ovoga istraživanja ispitati jesu li određene sociodemografske značajke odgojitelja (godine radnoga iskustva/radni staž i stručna sprema) povezane s određenim aspektima kvalitete partnerske suradnje u ustanovama ranoga i predškolskoga odgoja i obrazovanja u vrijeme pandemije koronavirusa.

U skladu s navedenim, u radu su postavljene sljedeće hipoteze:

H1 Odgojitelji se samoprocjenjuju kompetentnima u provođenju kvalitetne partnerske suradnje s roditeljima u vrijeme izvanrednih životnih okolnosti izazvanih pandemijom bolesti COVID-19.

H2 Postoji statistički značajna povezanost između godina radnoga iskustva i stručne spreme odgojitelja s kvalitetom partnerske suradnje $\mathrm{s}$ roditeljima u vrijeme pandemije bolesti COVID-19.

H3 Postoji statistički značajna razlika između odgojitelja s obzirom na njihove godine radnoga iskustva u procjeni kvalitetne komunikacije putem digitalnih medija u procesu razvoja partnerskih odnosa $s$ roditeljima $u$ vrijeme pandemije bolesti COVID-19. emphasised the importance of the educator when creating comfortable environments that are essential for the close relationship between the parents and the educators, as well as the educator's desire to try to strengthen that partnership. Quality child care in the early childhood and preschool phase contributes to the emotional, social, and intellectual development of children and represents their ability to learn. This is why quality early childhood and preschool care and support are useful to children with disabilities, as well as to children without disabilities. In that sense, in order to provide support to parents and children with disabilities, educators have to be sensitised, feel competent, and set goals that will motivate parents to cooperate and form partnerships that can help create many possibilities for authentic family engagement.

\section{AIM AND RESEARCH HYPOTHESES}

Given that there is still not enough research in the Republic of Croatia that deals with analysing the quality of partnerships during the COVID-19 pandemic from a pedagogical perspective, this study aimed to analyse whether sociodemographic factors of educators (years of work experience/ years of working in the field, and professional qualifications) are associated with certain aspects of the quality of partnerships and cooperation in early childhood and preschool education institutions during the COVID-19 pandemic.

The following hypotheses were proposed:

H1 Educators self-assess themselves as competent in conducting quality partnerships and cooperating with parents during the out-ofthe-ordinary life circumstances caused by the COVID-19 pandemic.

$\mathrm{H} 2$ There is a statistically significant correlation between the quality of partnerships and cooperation with parents during the COVID-19 pandemic and the number of years of work experience and professional qualifications of educators.

H3 There is a statistically significant difference between educators, based on their work experience, when it comes to their assessment of quality communication via digital media in the process of developing partnerships with parents during the COVID-19 pandemic. 


\section{METODE RADA}

\section{Uzorak ispitanika}

Uzorkom je obuhvaćeno 313 odgojitelja, od toga 312 ženskog te jedan muškoga spola. Što se tiče obrazovanja $2,2 \%$ odgojitelja ima srednju stručnu spremu (SŠ), 86,6\% dvogodišnji ili trogodišnji studij (VŠS), a 11,2\% četverogodišnji ili petogodišnji studij (VSS). Tablica 1 prikazuje godine radnoga staža odgojitelja u uzorku.

\section{Mjerni instrument i obrada podataka}

Ovaj je rad dio istraživačkoga projekta Istraživanje partnerstva u ustanovama ranog odgoja u vrijeme pandemije koronavirusa (2020/2021), a koji se nadovezuje na ciljeve projekta: Istraživanje inkluzivne prakse i partnerstva $s$ roditeljima iz perspektive odgojitelja $i$ učitelja (2018/2019), Učiteljski fakultet Sveučilišta u Zagrebu (2018/2019; 2020/2021, voditeljica Anka Jurčević Lozančić). Za potrebe ovoga istraživanja, konstruiran je Upitnik o kvaliteti partnerske suradnje odgojitelja i roditelja u vrijeme izvanrednih životnih okolnosti izazvanih pandemijom bolesti COVID-19, a koji se sastoji od 28 čestica. U prvom, općem dijelu, pitanja su se odnosila na sociodemografska obilježja ispitanika (spol, radno iskustvo, stručna sprema). U drugom dijelu koji se sastoji od 25 čestica, a koje su mjerene na petostupanjskoj skali Likertova tipa ( 1 - nikada, 2 - rijetko, 3 - ponekad, 4 - često, 5 - redovito), odgojitelji su procjenjivali svoje poimanje kompetentnosti u realizaciji partnerstva primjenom suvremenih modaliteta suradnje. Popunjavanje upitnika provodilo se izravno u ustanovama ranoga odgoja i obrazovanja grada Zagreba, u skladu s najvišim etičkim standardima i standardima odgovorne provedbe istraživanja. To je uključivalo znanstvenu čestitost, kolegijalnost, zaštitu ispitanika te društvenu odgovornost. Također je sukladno Etičkom kodeksu Odbora za etiku u znanosti i visokom obrazovanju (2006) bilo

\section{RESEARCH METHODOLOGY}

\section{Sample}

The sample comprised of 313 educators, of which 312 were women, and 1 was a man. About $2.2 \%$ of the educators had completed secondary education (secondary school graduates), 86.6\% had completed two- or three-years of post-secondary education, and $11.2 \%$ had completed four- or five-years of post-secondary education (university degree). Table 1 shows the number of years of work experience of all the educators in the sample.

\section{Measuring instrument and research methods}

This paper is a part of the research project Istraživanje partnerstva u ustanovama ranog odgoja u vrijeme pandemije COVID-19 ("Research into partnerships in early childhood institutions during the COVID-19 pandemic", 2020/2021), which builds on the aims of the project Istraživanje inkluzivne prakse i partnerstva s roditeljima iz perspektive odgojitelja i učitelja ("Research into inclusive practice and partnerships with parents from the educators and teachers' perspectives", 2018/2019) conducted at the Faculty of Teacher Education of the University of Zagreb (2018/2019; 2020/2021, head of the project is Anka Jurčević Lozančić).

For the purpose of this study, the Questionnaire about the quality of partnerships and cooperation between educators and parents during the out-of-theordinary life circumstances caused by the COVID-19 pandemic was developed constructed and it comprised 28 statements. In the first (general) part of the questionnaire, the statements were related to the sociodemographic factors of the respondents (sex, work experience, professional qualifications). The second part comprised of 25 statements that can be measured on a five-item Likert scale (1-never, 2-rarely, 3sometimes, 4-often, 5-regularly). Here the educators assessed their comprehension of the competency of parents to form a partnership by applying contempo-

Tablica 1. Prikaz godina radnoga iskustva odgojitelja / Table 1. Work experience of the educators

\begin{tabular}{|l|c|c|c|c|c|c|c|c|}
\hline Work experience in years & $<\mathbf{1}$ & $\mathbf{2 - 5}$ & $\mathbf{6}-\mathbf{1 0}$ & $\mathbf{1 1 - 1 5}$ & $\mathbf{1 6}-\mathbf{2 0}$ & $\mathbf{2 1 - 2 5}$ & $\mathbf{2 6}-\mathbf{3 0}$ & $\mathbf{>} \mathbf{3 0}$ \\
\hline Frequency & 61 & 58 & 53 & 34 & 25 & 19 & 18 & 45 \\
\hline Percentage (\%) & 19.5 & 18.5 & 16.9 & 10.9 & 8.0 & 6.1 & 5.8 & 14.4 \\
\hline Cumulative frequency & 19.5 & 38.0 & 55.0 & 65.8 & 73.8 & 79.9 & 85.6 & 100 \\
\hline
\end{tabular}


zajamčeno dobrovoljno sudjelovanje odgojitelja povjerljivost, tajnost $\mathrm{i}$ anonimnost podataka o ispitanicima.

Za statističku analizu u ovom istraživanju, prvotno su izračunati deskriptivni podaci čestica u upitniku (Tablica 2) te nakon toga korelacija istih s relevantnim sociodemografskim podacima. Kako bi se detaljnije proučile razlike u odgojiteljskoj procjeni zahtjevnosti suradnje s roditeljima putem digitalnih medija, primijenjena je ANOVA odnosno analiza varijance. Spomenuta je analiza provedena statističkim paketom SPSS-19.

\section{REZULTATI I RASPRAVA}

U Tablici 2 navedena je deskriptivna statistika za sve čestice u upitniku te su prikazane odgojiteljske procjene kvalitete partnerske suradnje s roditeljima u vrijeme izvanrednih životnih okolnosti izazvanih pandemijom koronavirusa. Uvidom u podatke iz tablice vidljivo je da odgojitelji u prosjeku postižu više rezultate na većini čestica, što znači da općenito kvalitetu partnerske suradnje u rary cooperation modalities. The questionnaire was filled out in early childhood educational institutions in Zagreb in accordance with the highest ethical standards and relevant conduct of research standards. These included scientific honesty, collegiality, protection of the respondents, and social responsibility. Moreover, in accordance with the Ethics Committee in Science and Higher Education (2006), the respondents were guaranteed voluntary participation, confidentiality, secrecy, and anonymity of their data.

First, the descriptive data from the questionnaire statements (Table 2) were analysed, and correlation coefficients were calculated for the descriptive data and relevant sociodemographic factors. To analyse the differences in the educators' assessment of the difficulties in cooperating with parents via digital media in greater detail, analysis of variance (ANOVA) was performed. This analysis was done in SPSS 19.

\section{RESULTS AND DISCUSSION}

Table 2 shows the descriptive statistics for all the questionnaire statements, as well as the educators'

Tablica 2. Prikaz deskriptivne statistike čestica u upitniku / Table 2. Descriptive statistics of the questionnaire statements

\begin{tabular}{|c|c|c|c|c|c|c|c|c|}
\hline Statements & & & & & & ewness & & urtosis \\
\hline & Min & Max & $\mathbf{M}$ & SD & Statistics & Standard error & Statistics & Standard error \\
\hline S1 & 1.00 & 5.00 & 3.38 & 1.152 & -0.168 & 0.138 & -0.835 & 0.275 \\
\hline $\mathrm{S} 2$ & 1.00 & 5.00 & 3.35 & 1.051 & -0.427 & 0.138 & -0.247 & 0.275 \\
\hline S3 & 1.00 & 5.00 & 3.76 & 1.136 & -0.635 & 0.138 & -0.510 & 0.275 \\
\hline S4 & 1.00 & 5.00 & 4.04 & 1.070 & -1.052 & 0.138 & 0.451 & 0.275 \\
\hline S5 & 1.00 & 5.00 & 2.31 & 1.119 & 0.497 & 0.138 & -0.588 & 0.275 \\
\hline S6 & 1.00 & 5.00 & 4.35 & 0.794 & -1.202 & 0.138 & 1.297 & 0.275 \\
\hline S7 & 2.00 & 5.00 & 4.53 & 0.693 & -1.503 & 0.138 & 2.085 & 0.275 \\
\hline S8 & 1.00 & 5.00 & 4.00 & 0.904 & -0.766 & 0.138 & 0.518 & 0.275 \\
\hline S9 & 1.00 & 5.00 & 4.16 & 0.861 & -0.974 & 0.138 & 0.760 & 0.275 \\
\hline S10 & 1.00 & 5.00 & 3.71 & 0.913 & -0.670 & 0.138 & 0.566 & 0.275 \\
\hline S11 & 2.00 & 5.00 & 4.32 & 0.708 & -0.881 & 0.138 & 0.676 & 0.275 \\
\hline S12 & 1.00 & 5.00 & 4.35 & 0.741 & -1.048 & 0.138 & 1.133 & 0.275 \\
\hline S13 & 2.00 & 5.00 & 4.24 & 0.819 & -0.786 & 0.138 & -0.190 & 0.275 \\
\hline S14 & 1.00 & 5.00 & 3.80 & 0.854 & -0.539 & 0.138 & 0.401 & 0.275 \\
\hline S15 & 1.00 & 5.00 & 3.31 & 1.111 & -0.234 & 0.138 & -0.604 & 0.275 \\
\hline S16 & 1.00 & 5.00 & 3.88 & 1.094 & -0.969 & 0.138 & 0.443 & 0.275 \\
\hline S17 & 2.00 & 5.00 & 4.30 & 0.768 & -0.793 & 0.138 & -0.180 & 0.275 \\
\hline S18 & 1.00 & 5.00 & 3.70 & 0.873 & -0.452 & 0.138 & 0.137 & 0.275 \\
\hline S19 & 1.00 & 5.00 & 3.17 & 1.071 & -0.169 & 0.138 & -0.645 & 0.275 \\
\hline S20 & 1.00 & 5.00 & 3.88 & 0.803 & -0.523 & 0.138 & 0.385 & 0.275 \\
\hline S21 & 2.00 & 5.00 & 3.66 & 0.923 & -0.442 & 0.138 & 0.038 & 0.275 \\
\hline S22 & 1.00 & 5.00 & 3.78 & 0.927 & -0.439 & 0.138 & -0.071 & 0.275 \\
\hline S23 & 1.00 & 5.00 & 2.74 & 1.023 & 0.380 & 0.138 & -0.104 & 0.275 \\
\hline S24 & 1.00 & 5.00 & 3.36 & 1.177 & -0.198 & 0.138 & -0.826 & 0.275 \\
\hline S25 & 1.00 & 5.00 & 3.66 & 1.044 & -0.496 & 0.138 & -0.241 & 0.275 \\
\hline
\end{tabular}


Legenda - tvrdnje (T): T1 - U radu s roditeljima $i$ djecom imam/imala/o sam pomoć stručnih suradnika $u$ svojem vrtiću; T2 - Pomogla su mi stručna usavršavanja koja sam završila/o, a odnosila su se na suradnju i rad s roditeljima općenito; T3 - Smatram se kompetentnom/ im $u$ korištenju digitalne tehnologije jer sam ju koristila/o i prije za komunikaciju s roditeljima; T4 Posjedujem potrebne digitalne vještine za suradnju $i$ izmjenu informacija s ostalim odgojiteljima i stručnim suradnicima.; T5 - Imala/o sam određene poteškoće u uspostavljanju suradnje s roditeljima $u$ online-okruženju;

T6 - Kompetentna/an sam graditi i uspostavljati partnerske i suradničke odnose s roditeljima sve djece, pa tako is roditeljima djece s teškoćama; T7 - Kompetentna/an sam pružati potporu roditeljima djece iz moje skupine; T8 Kompetentna/an sam pružiti pomoć roditeljima djece $s$ teškoćom u prepoznavanju njihovih prioriteta u odnosu na daljni razvoj njihovog djeteta; T9 - Kompetentnal an sam savjetovati i uključivati roditelje u planiranje rada s djetetom kod kuće; T10-Ocjenjujem vlastiti rad u suradnji s roditeljima o postavljanju ciljeva, načina mojega rada, komunikacije, ishoda i rezultata; T11 Uvažavam izbore $i$ ciljeve roditelja za njihovo dijete $i$ učinkovito komuniciram s njima o djetetovu napretku; T12 - Optimistična/an sam u pogledu veće suradnje $i$ stvaranja partnerstva s roditeljima; T13 - Vrtići i roditelji imaju zajednički cilj kako bi se realizirali najbolji ishodi za njihovu djecu; T14 - Moja iskustva o uporabi učinkovitih strategija koje koristim u suradnji s roditeljima za učenje djece kod kuće su pozitivna; T15 - Učinkovit online-rad s roditeljima mi je izazov; T16 - Tijekom online-suradnje s roditeljima svakodnevno kreiram ozračje koje se temelji na međusobnom razumijevanju, uzajamnoj pomoći, poštivanju i poticanju zajedničkih aktivnosti djece; T17 - Za stvaranje partnerstva s roditeljima potrebna je moja upornost, napor i iskazivanje volje roditelja za podrškom; T18 Ostvarujem individualnu suradnju s roditeljima koji su bili manje uključeni u zajedničku suradnju na razini odgojne skupine; T19 - Smatram da većina vrtića ima plan za rad odgojitelja $u$ online-okruženju; T20-Motiviram roditelje za rads djetetom radi prevencije njihove zabrinutosti i/ ili nedostatka interesa za omiljene aktivnosti i igru $s$ djetetom; T21-Roditelji me izvješćuju o djetetovu napretku i razvoju; T22 - Komunikacija s roditeljima zahtjevnija je kad se ostvaruje putem digitalnih medija; T23 - Osjećam veći pritisak i nezadovoljstvo od strane roditelja, kad se suradnja odvija online; T24-Za daljnji razvoj mojih kompetencija za stvaranje partnerstva s roditeljima online, potrebno mi je dodatno teorijsko usavršavanje; T25-Za daljnji razvoj mojih kompetencija za stvaranje partnerstva $s$ roditeljima online, potrebno je veće praktično iskustvo o prilagođavanju aktivnosti.

vrijeme pandemije procjenjuju visokom. Drugim riječima, vidljivo je da se smatraju kompetentnima u izgradnji i uspostavljanju partnerskih odnosa s roditeljima $(M=4,35$, uz $S D=, 794)$, kao i u
Legend - Statements (S): S1-While working with parents and children, I've had help from professional associates in my kindergarten; S2-Professional training that I've completed, and that was dealing with cooperation and working with parents in general, has helped me; S3-I consider myself competent in using digital technology because I have used it before as a way to communicate with parents; S4-I possess the required digital skills for cooperation and information sharing with other educators and professional associates; S5-I've had certain difficulties in establishing cooperation with parents in an online environment; S6-I am competent to establish and maintain partnerships and cooperation with parents of all children, including children with disabilities; S7-I am competent to provide support to parents of children who are in my kindergarten class; S8-I am competent to help parents of children with disabilities in recognizing their priorities when it comes to the further development of their child; S9-I am competent to advise and include parents in planning what to do with their child at home; S10-I evaluate my own work in cooperating with parents in order to set goals, my way of work, communication, outcomes, and results; S11-I respect the choices and goals that parents have set out for their child and I effectively communicate with them about their child's progress; S12-I am optimistic when it comes to greater cooperation and establishing partnerships with parents; S13-Kindergartens and parents have a mutual goal, and that is to realise the best outcomes for the children; S14-My experience in using effective strategies for cooperation with parents for learning at home are positive; S15-Effective online work with parents presents a challenge for me; S16-During online cooperation with parents, I create an environment based on mutual understanding, help, respect, and encouragement of joint activities with children every day; S17-My persistence, hard work, and the expression of will for my support by the parents are needed for establishing partnerships with parents; S18-I establish individual cooperation with parents who have been less involved in mutual cooperation in the kindergarten class; S19-I think most kindergartens have a plan for educator's work in an online environment; S20-I motivate parents to work with their children in order to prevent their concern and/or lack of interest for favourite activities and playtime with the child; T21-Parents report back to me on their child's progress and development; S22-Communication with parents is more difficult via digital media; S23-I feel greater pressure and dissatisfaction from parents when the cooperation is performed online; S24-I need theoretical knowledge for further development of my competencies to establish online partnerships with parents; S25-I need more practical experience in adapting activities for the further development of my competencies to establish online partnership with parents.

assessments of the quality of partnerships and cooperation with parents during the out-of-the-ordinary life circumstances caused by the COVID-19 pandemic. The data indicates that educators on average 
pružanju potpore roditeljima $(M=4,53$, uz $S D=$ ,693). Pritom je važno naglasiti kako odgojitelji najčešće navode svoja pozitivna iskustva jer uspijevaju prepoznati i uvažavati izbore i ciljeve roditelja za njihovo dijete $(M=4,32$, uz $S D=, 708)$ te su optimistični u pogledu iniciranja suradnje i jačanju partnerstva $(M=4,35$, uz $S D=, 741)$. Usto za stvaranje partnerstva s roditeljima visoko vrednuju upornost, napor i volju (želju) kao bitne značajke koje potiču proces razvoja kvalitete partnerstva $(M$ $=4,30$, uz $S D=, 768)$. Međutim, kao što pokazuju rezultati Tablice 2 , ponekad spominju poteškoće $\mathrm{u}$ uspostavljanju suradnje s roditeljima u onlineokruženju $(M=2,31$, uz $S D=1,119)$ iako prema njihovim navodima uglavnom posjeduju potrebne digitalne vještine $(M=4,04$, uz $S D=1,070)$. Slijedom navedenoga i uvidom u ranije navedene činjenice hipoteza $\mathrm{H} 1$ djelomično se prihvaća te je opravdano zaključiti kako odgojitelji smatraju da je komunikacija s roditeljima ponekad zahtjevnija kada se ostvaruje putem digitalnih medija $(M=$ 3,78 , uz $S D=$,927). Također, daljnjim uvidom u podatke Tablice 2, zaključuje se da je komunikacija sa stručnim suradnicima koji su ključni u osmišljavanju i evaluaciji programa za djecu s teškoćama, uglavnom izostala. Odgojitelji naglašavaju da su samo ponekad u radu s roditeljima i djecom imali pomoć stručnih suradnika $(M=3,38$, uz $S D$ $=1,152)$. Unatoč navedenom smatraju se dovoljno kompetentnima pružiti pomoć roditeljima djece s teškoćama u prepoznavanju njihovih prioriteta u odnosu na daljnji razvoj njihova djeteta $(M=$ $4,00$, uz $S D=, 904)$. Iz navedenoga proizlazi da odgojitelji donose odluke koje utječu na dobrobit za razvoj, odgoj i obrazovanje djece s teškoćama. Kada se ove odluke temelje na kompetencijama o osobitostima razvoja i učenja djeteta s teškoćom, o aktivnostima, sredstvima i materijalima, interakcijama ili iskustvima djece s teškoćama, zasigurno će se razvijati i poticati inkluzivna praksa. Suradnja s ciljem ublažavanja teškoća u dijalogu sa stručnim suradnikom od velike je važnosti, što pretpostavlja da prilikom planiranja individualiziranih aktivnosti odgojitelj se ne bi trebao osjećati usamljeno, već bi to trebao biti pristup koji je zasnovan na međusobnoj pomoći i interdisciplinarnoj suradnji sa stručnim suradnicima (Kudek Mirošević, Tot i Šamo, 2020). achieve higher results in most of the statements, which means that, in general, they assess that the quality of partnership and cooperation during the pandemic is high. In other words, it is noticeable that they consider themselves competent in building and establishing partnerships and relationships with parents of all children $(M=4.35$, with $S D=0.794)$, as well as in providing support to the parents $(M=4.53$, with $S D=$ 0.693). Furthermore, it is important to emphasise that, in most cases, the educators talk about their positive experiences because they managed to recognise and respect the choices and goals that the parents set out for their children $(M=4.32$, with $S D=0.708)$, and are optimistic when it comes to initiating cooperation and strengthening partnerships $(M=4.35$, with $S D=$ 0.741). Moreover, to establish partnerships with parents, educators think that persistence, hard work, and willingness (desire) are important factors that prompt the process of quality partnership development $(M$ $=4.30$, with $S D=0.768$ ). However, as the results in Table 2 show, sometimes they come across difficulties in establishing cooperation with parents in an online environment $(M=2.31$, with $S D=1.119)$, even though, according to their statements, they usually possess the necessary digital skills $(M=4.04$, with $S D=1.070)$. By analysing these results and the statements mentioned earlier, the hypothesis $\mathrm{H} 1$ was partially accepted; it can be concluded that educators think that communication with parents is sometimes more difficult when performed via online media $(M=$ 3.78 , with $S D=0.927)$. Also, after analysing the data in Table 2 in detail, it was observed that communication with professional associates, who are crucial to the formation and evaluation of programmes for children with disabilities, was usually missing. The educators emphasise that they have rarely had help from professional associates when working with parents and children $(M=3.38$, with $S D=1.152)$. Despite that, they consider themselves competent enough to provide help to parents of children with disabilities to recognise the priorities for the further development of their child $(M=4.00$, with $S D=0.904)$. This leads to the conclusion that educators make decisions that affect the welfare, development, and education of children with disabilities. When these decisions are based on competencies related to the development and learning abilities of children with disabilities, as well as the activities, means and materials, interactions, or experiences of children with disabilities, inclusive 
Nadalje prema hipotezi H2, kako bi se utvrdila povezanost odgojiteljskih procjena kvalitete partnerske suradnje s roditeljima u vrijeme izvanrednih životnih okolnosti izazvanih pandemijom koronavirusa i godina radnoga iskustva te stručne spreme odgojitelja, u Tablici 3 izračunati su koeficijenti korelacije koji su, radi lakšega praćenja u daljnjem tekstu, navedeni u zagradama. $U$ tu svrhu potrebno je napomenuti kako je korelacija između samoprocjene partnerske suradnje i godina radnoga iskustva prikazana Pearsonovim koeficijentom korelacije. Nadalje korelacija između samoprocjene kvalitete partnerske suradnje i stručne spreme prikazana je Spearmanovim koeficijentom. Spearmanov koeficijent korelacije (produkt ranga korelacije) koristi se za mjerenje povezanosti između varijabli u slučajevima kada nije moguće primijeniti Pearsonov koeficijent korelacije, odnosno kada neke od pretpostavki poput skale mjerenja nisu zadovoljene (Milas, 2005). Prema practice must definitely be developed and encouraged. Cooperation with professional associates with the goal to help children with disabilities is especially important, which assumes that planning individualised activities should not be the educator's task alone, but it should be an approach based on mutual help and interdisciplinary cooperation with the professional associates (Kudek Mirošević, Tot and Šamo, 2020).

Furthermore, with respect to hypothesis H2, i.e., to determine the correlation between the educators' assessments of the quality of partnerships and cooperation with parents during the out-of-the-ordinary life circumstances caused by the COVID-19 pandemic and their years of work experience and professional qualifications, correlation coefficients were calculated in Table 3 and are hereinafter listed in brackets. The correlation between self-assessment of partnerships and cooperation and the number of years of work experience was calculated using the Pearson correla-

Tablica 3. Prikaz korelacije čestica u upitniku sa sociodemografskim varijablama / Table 3. Correlation between the questionnaire statements and sociodemographic factors

\begin{tabular}{|c|c|c|}
\hline Statements & Work experience in years & Professional qualification \\
\hline $\mathrm{S} 1$ & -0.060 & -0.015 \\
\hline S2 & $0.124^{*}$ & 0.005 \\
\hline S3 & $-0.497 * *$ & $0.188^{*}$ \\
\hline S4 & $-0.503 *$ & $0.220 * *$ \\
\hline S5 & $0.290 * *$ & -0.086 \\
\hline S6 & -0.007 & 0.108 \\
\hline S7 & 0.073 & 0.094 \\
\hline S8 & 0.053 & 0.086 \\
\hline S9 & -0.079 & $0.161 * *$ \\
\hline S10 & $0.146^{* *}$ & $0.155^{* *}$ \\
\hline S11 & 0.080 & $0.149 * *$ \\
\hline S12 & -0.087 & $0.167 * *$ \\
\hline $\mathrm{S} 13$ & 0.085 & $0.158 * *$ \\
\hline S14 & -0.017 & $0.214 * *$ \\
\hline S15 & -0.093 & $0.175 * *$ \\
\hline S16 & $-0.176^{* *}$ & $0.163 * *$ \\
\hline S17 & -0.053 & $0.142 *$ \\
\hline S18 & $0.155^{* *}$ & $0.167 * *$ \\
\hline S19 & 0.053 & $0.424 * *$ \\
\hline S20 & 0.001 & $0.185 * *$ \\
\hline S21 & 0.021 & $0.165 * *$ \\
\hline S22 & $0.199 * *$ & -0.094 \\
\hline S23 & $0.143^{*}$ & $-0.111 *$ \\
\hline S24 & $0.321 * *$ & -0.026 \\
\hline $\mathrm{S} 25$ & $0.183 * *$ & -0.064 \\
\hline
\end{tabular}

$*$ level of significance $=0.05 ; * *$ level of significance $=0.01$ 
podacima navedenim u Tablici 3 vidljivo je kako je stručna sprema u najvećoj negativnoj korelaciji s česticama T3 i T4. Slijedom navedenoga opravdano je zaključiti da se odgojitelji s više godina radnoga staža smatraju manje kompetentnima u korištenju digitalne tehnologije $(r=-, 497 * *)$ te navode kako posjeduju slabije razvijene digitalne vještine potrebne za suradnju i online-izmjenu informacija $\left(r=-, 503^{* *}\right)$. Također ako imaju više godina radnoga staža, procjenjuju veće poteškoće $u$ uspostavljanju suradnje s roditeljima u online-okruženju $\left(r=, 290^{* *}\right)$. Bitno je naglasiti kako postoji značajna pozitivna korelacija s česticama T24 i T25, odnosno odgojitelji s više radnoga iskustva iskazuju kako im je za daljnji razvoj kompetencija za online-suradnju potrebno dodatno teorijsko usavršavanje $\left(r=, 321^{* *}\right)$, ali i veće praktično iskustvo o prilagodbi aktivnosti svakom djetetu $\left(, 183^{* *}\right)$, pa upravo ove vještine ističu značajnim u odgojiteljskoj kompetenciji za suradnju s roditeljima. Naime planiranje i odabir adekvatnih strategija podrške u individualiziranom pristupu ovise o individualnim snagama, interesima i potrebama svakog pojedinoga djeteta u odgojnoj skupini. U okviru kulturnoga i socijalnoga konteksta u kojem djeca odrastaju prepoznavanje sociokulturnih utjecaja osigurava da iskustva u učenju svakoga djeteta budu smislena, relevantna i prilagođena djeci u skladu s njihovim sposobnostima i mogućnostima, kao i s mogućnostima njihovih obitelji (Thompson, 2015).

Nadalje što se tiče stručne spreme moguće je istaknuti da ako odgojitelji imaju višu stručnu spremu, smatraju se kompetentnijima za korištenje digitalne tehnologije i razvoja online-komunikacije $\left(r=, 220^{* *}\right)$. Također viša je stručna sprema u međuodnosu s pozitivnim iskustvima tijekom uporabe učinkovitih strategija suradnje s roditeljima za učenje djece kod kuće $\left(r=, 214^{* *}\right)$. Zanimljivo je da, kako pokazuju rezultati ovoga istraživanja, odgojitelji koji imaju višu stručnu spremu češće motiviraju roditelje za rad s djetetom radi prevencije njihove zabrinutosti $\mathrm{i} /$ ili nedostatka interesa za igru s djetetom $\left(r=, 185^{* *}\right)$. Uz navedeno pozitivna korelacija povezana je sa stručnom spremom i procjenom odgojitelja da većina ustanova za rani i predškolski odgoj i obrazovanje ima plan za rad u online-okruženju u vrijeme pandemije koronavirusa $\left(r=, 424^{* *}\right)$. Kada se govori o djeci s teškoćama, tion coefficient. The correlation between the self-assessment of the quality of partnerships and cooperation and professional qualifications was calculated using the Spearman's coefficient. The Spearman's correlation coefficient (the product of correlation rank) is used for measuring the correlation between variables in cases when the Pearson correlation coefficient cannot be used, i.e., when some of the preconditions such as the measurement scale are not satisfied (Milas, 2005). According to the data in Table 3, the biggest negative correlation was observed between professional qualifications and statements S3 and S4. This indicates that educators with a greater number of years of work experience consider themselves less competent while using digital technology $\left(r=-0.497^{* *}\right)$, and they think that they possess very few digital skills necessary for cooperation and information sharing online. $(r=$ $\left.-0.503^{* *}\right)$. Furthermore, if they have a greater number of years of work experience, they report that they face greater difficulties in establishing cooperation with parents in an online environment $\left(r=0.290^{* *}\right)$. It should be noted that there is a statistically significant correlation between statements S24 and S25, i.e., that educators with more years of work experience state that, for further development of competencies for online cooperation, they need additional theoretical knowledge $\left(r=0.321^{* *}\right)$ and more practical experience in adapting activities for each child $\left(0.183^{* *}\right)$. Therefore, these skills are considered to be valuable among the competencies of educators for quality cooperation with parents. For example, planning and choosing adequate support strategies in an individualised approach depending on the individual forces, interests, and needs of every child in the kindergarten class. In the cultural and sociological context in which these children grow up, recognizing sociocultural influences ensures that every child's experience of learning has meaning, relevance, and is appropriate to their individual abilities and capabilities, as well as their family's possibilities (Thompson, 2015).

Considering professional qualifications, if educators acquired higher degrees of professional qualifications, they would consider themselves more competent for using digital technology and developing online communication $\left(r=0.220^{* *}\right)$. Also, higher professional qualifications are interrelated to positive experiences in using effective strategies for cooperation with parents regarding learning at home 
uvidom u rezultate vidljivo je kako ne postoji povezanost između godina radnoga staža te ostvarene stručne spreme sa samoprocjenama kompetentnosti pružanja podrške i pomoći roditeljima djece s teškoćama. Drugim riječima, čini se kako procjena kompetencije za suradnju s roditeljima djece s teškoćama ne ovisi o sociodemografskim osobinama odgojitelja mjerenim u ovom istraživanju.

Nadalje kako bi se provjerilo postoji li statistički značajna razlika u procjeni zahtjevnosti suradnje s roditeljima online, kao i nezadovoljstva od strane roditelja, a s obzirom na radno iskustvo odgojitelja, korištena je analiza varijance. Dakle za ispitivanje hipoteze H3, procjenjuju li odgojitelji različitoga radnoga iskustva drukčije zahtjevnost suradnje s roditeljima putem digitalnih medija, a ujedno i nezadovoljstvo te pritisak od strane roditelja, bitno je napomenuti kako je provedena transformacija varijable radnoga iskustva da se ujednači broj sudionika prema skupinama, što je vidljivo u tablici deskriptivnih podataka (Tablica 4). Također kao zavisna varijabla korišten je prosjek dvaju slje- $\left(r=.214^{* *}\right)$. Based on the results of the present study, it is interesting to see that educators who acquired higher professional qualifications motivated parents to work with their child more often in order to prevent their concern and/or lack of interest for playtime with the child $\left(r=0.185^{* *}\right)$. Moreover, there is a positive correlation between professional qualifications and the educators' assessment that most preschool institutions have a plan for work in an online environment during the COVID-19 pandemic $(r=0.424 * *)$. When it comes to children with disabilities, the results show that there is no correlation between the number of years of work experience and professional qualifications on the one side and self-assessment of one's own competency in providing support and help to parents of children with disabilities on the other. In other words, it seems as though the assessment of competency for cooperation with parents of children with disabilities does not depend on the sociodemographic factors of the educators included in this study.

Analysis of variance was used to test if there was a statistically significant difference in assessing the difficulty of cooperation with parents online, as well
Tablica 4. Deskriptivni podaci / able 4. Descriptive data

\begin{tabular}{|l|c|c|c|}
\hline $\begin{array}{l}\text { Work } \\
\text { experience in } \\
\text { years }\end{array}$ & M & SD & N \\
\hline$<5$ & 3.0924 & 0.79981 & 119 \\
\hline $6-15$ & 3.2701 & 0.75021 & 87 \\
\hline$>16$ & 3.4299 & 0.85077 & 107 \\
\hline Total & 3.2572 & 0.81462 & 313 \\
\hline
\end{tabular}

Tablica 5. Sažetak ANOVA-e / Table 5. Summary of ANOVA

\begin{tabular}{|c|c|c|c|c|c|}
\hline $\begin{array}{l}\text { Source of } \\
\text { variability }\end{array}$ & $\begin{array}{l}\text { Sum of } \\
\text { squares }\end{array}$ & $\begin{array}{l}\text { Degrees } \\
\text { of } \\
\text { freedom }\end{array}$ & $\begin{array}{c}\text { Mean } \\
\text { sum of } \\
\text { squares }\end{array}$ & $\mathbf{F}$ & $\mathbf{P}$ \\
\hline $\begin{array}{l}\text { Work experience } \\
\text { Within the groups/ } \\
\text { Error }\end{array}$ & $\begin{array}{c}6.427 \\
200.610\end{array}$ & $\begin{array}{c}2 \\
310\end{array}$ & $\begin{array}{l}3.218 \\
0.647\end{array}$ & 4.973 & 0.007 \\
\hline Total & 3527.750 & 313 & & & \\
\hline
\end{tabular}

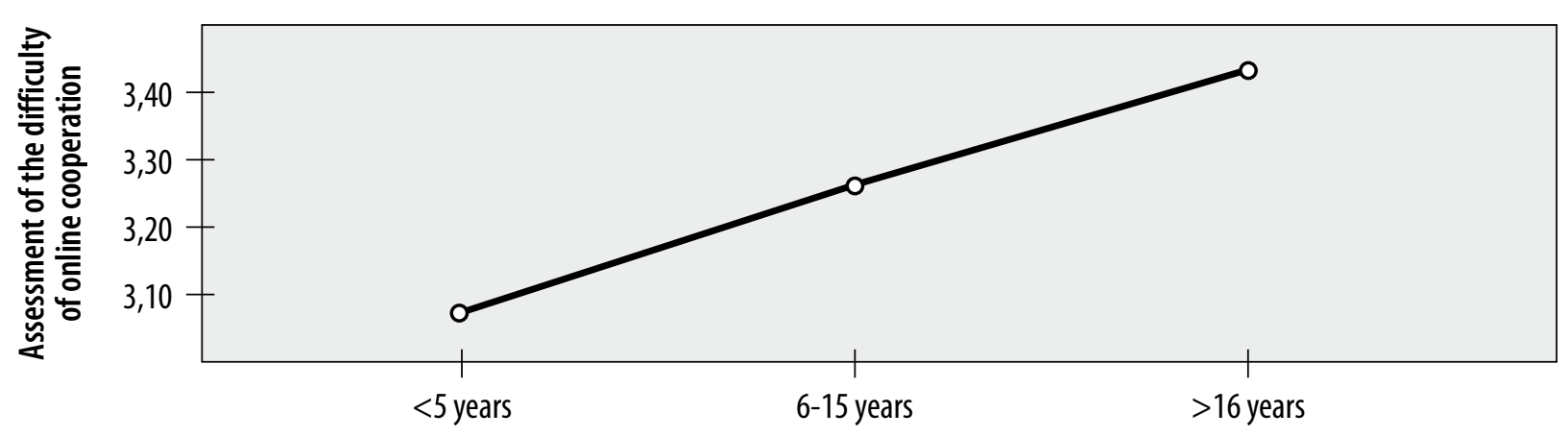

The educators' work experience

Grafički prikaz 1. Aritmetičke sredine procjene zahtjevnosti online suradnje s obzirom na radno iskustvo odgojitelja / Figure 1. Arithmetic mean of the self-assessment of the educators' competencies to establish online cooperation considering their work experience 
dećih čestica koje su se pokazale faktorski bliske i opravdane za kombinaciju: 1) Komunikacija s roditeljima zahtjevnija je kad se ostvaruje putem digitalnih medija (T22) te 2) Osjećam veći pritisak i nezadovoljstvo od strane roditelja kad se suradnja odvija online (T23). Uz navedeno bitno je naglasiti kako su u provedenoj ANOVA-i varijance kroz razine homogene, što je dokazano Leveneovim testom. ( $F=, 0481, \mathrm{uz} d f 1=2$, $d f=310$ te $p=, 618)$. Iako raspodjele značajno odstupaju od normaliteta, ANOVA je robusna na manja odstupanja jer su raspodjele simetrične ili asimetrične $u$ istom smjeru. Rezultati ANOVA-e prikazani su u sljedećim tablicama i sumirani na Grafičkom prikazu 1.

$\mathrm{S}$ obzirom na dobivene rezultate $\mathrm{u}$ Tablici 5 može se zaključiti kako postoje statistički značajne razlike u procjeni zahtjevnosti onli$n e$-suradnje s roditeljima s obzirom na radno iskustvo odgojitelja, na način da odgojitelji koji imaju više godina radnoga iskustva onli$n e$-suradnju s roditeljima smatraju zahtjevnijom i osjećaju više pritiska od strane roditelja $(\mathrm{F}=4,973$, uz $d f 1=2, d f 2=310$ te $p=0,007)$. Posthoc testiranjem (Fisher LSD test) detaljnije je pokazano kako se značajno razlikuju odgojitelji s najmanje i s najviše godina radnoga iskustva, kao što je vidljivo i na Grafičkom prikazu 1. Dakle razlikuju se odgojitelji koji imaju manje od pet godina i više od 16 godina radnoga iskustva, na način da se odgojitelji s manje godina iskustva bolje snalaze u suradnji putem digitalnih medija (uz $p=0,002$ ). Uz prednosti koje donosi digitalna tehnologija, Viber, WhatsApp, SMS, elektronička pošta i drugi, komunikaciju čine funkcionalnijom, bržom i lakše dostupnom, omogućen je brži protok informacija između odgojitelja i roditelja (Morgan, 2017) potrebno je sagledati i probleme koji dolaze uz njezino još uvijek nedovoljno korištenje. Razlog je tome zasigurno i taj što se i danas tijekom inicijalnoga obrazovanja, a i kasnije tijekom daljnjega profesionalnoga usavršavanja, ne razvijaju potrebne kompetencije za korištenje digitalne tehnologije. Kao što pokazuju rezultati ovoga istraživanja hipoteza $\mathrm{H} 3$ se prihvaća te se prepoznaju generacijske razlike između odgojitelja mlađe životne dobi i s manje godina radnog iskustva, as the dissatisfaction of parents with the educator's work experience. Therefore, to test hypothesis $\mathrm{H} 3$ - do educators with different levels of work experience assess themselves differently with respect to the difficulties associated with cooperating with parents via digital media, and the dissatisfaction and pressure from the parents - the work experience variable was transformed to even out the number of respondents in the groups (Table 4). The median of the following two statements was also used as an independent variable, and these were observed to have similar response patterns, further justifying this combination: 1) Communication with parents is more difficult via digital media (S22), and 2) I feel greater pressure and dissatisfaction from parents when the cooperation is performed online (S23). It is also important to mention that, based on the ANOVA test, variances were homogeneous throughout the groups; this was confirmed using Levene's test $(F=0.0481, d f 1=2, d f=310, p$ $=0.618$ ). Even though the distributions deviated significantly from the normal distribution, the results of the ANOVA were robust to minor deviations because the distributions were symmetrical or asymmetrical in the same direction. The ANOVA test results are shown in Tables 4 and 5 and summarised in Figure 1.

Considering the results in Table 5, there are statistically significant differences in the assessment of the difficulty of online cooperation with parents depending on the work experience of educators. The educators who had a greater number of years of work experience found online cooperation more difficult and felt more pressure from the parents $(\mathrm{F}$ $=4.973, d f 1=2, d f 2=310, p=0.007)$. A post-hoc test (Fisher LSD test) showed in greater detail that there is a significant difference between educators with the lowest and the highest number of years of work experience (Figure 1). Thus, there is a difference between educators who have less than 5 years and more than 16 years of work experience, where the educators with fewer years of work experience handle cooperation via online media better ( $p=$ $0.002)$. With all the advantages digital technology has to offer, Viber, WhatsApp, text messages, and emails make communication more functional, faster, and more accessible, resulting in a faster flow of information between educators and parents (Morgan, 2017). However, the problems that come with the lack of use of digital technology still need 
dakle onih koji odrastaju s novim tehnologijama i onih kojima je to novost u zreloj životnoj dobi i s više godina radnoga iskustva, što utječe na njihove kompetencije.

\section{ZAKLJUČAK}

Jedinstveni kulturni, etnički i govorni aspekti obiteljske zajednice kao i njihova moralna ili ruralna priroda nude $\mathrm{i}$ otvaraju brojne prilike $\mathrm{i}$ izazove za osnaživanjem partnerstva. Davanje i pomaganje sastavni su dijelovi kulture u koje je utkan suživot drugih i drukčijih (Ward, 2013), riječ je o otvaranju mogućnosti za nove susrete, dijeljenju ideja i vrijednosti koji generiraju suštinu partnerstva (Jackson i Needham, 2014). Na razini odgojno-obrazovne ustanove to znači prepoznati i poštivati potrebe obitelji, autentičnost roditeljstva, ali i važnost njegovanja bliskih odnosa roditelja i djece te u skladu s tim kreirati različite oblike podrške koji će pridonijeti njihovu osnaživanju. Rezultati provedenog istraživanja pokazuju kako odgojitelji kvalitetu partnerske suradnje s roditeljima u vrijeme pandemije koronavirusa općenito procjenjuju visoko te su optimistični u pogledu iniciranja suradnje i jačanja partnerstva. Vidljivo je da se smatraju kompetentnima u građenju partnerskih odnosa s roditeljima, kao i u pružanju pomoći roditeljima djece $\mathrm{s}$ teškoćama u prepoznavanju prioriteta u odnosu na daljnji djetetov razvoj. Što se tiče radnog iskustva odgojitelji s više godina radnog iskustva smatraju se manje kompetentnima u korištenju digitalne tehnologije te naglašavaju kako im u tom aspektu treba više teorijskog usavršavanja i praktičnog iskustva. Kada se detaljnije osvrnemo na procjenu zahtjevnosti suradnje s roditeljima online, može se zaključiti kako se značajno razlikuju odgojitelji s najmanje i s najviše godina radnog iskustva, na način da se odgojitelji s manje godina radnog iskustva bolje snalaze u suradnji putem digitalnih medija. Nadalje što se tiče stručne spreme odgojitelja potrebno je istaknuti da se odgojitelj koji imaju višu stručnu spremu smatraju kompetentnijima za korištenjem digitalne tehnologije, a isto tako smatraju kako redovitije motiviraju roditelje za rad s djetetom radi prevencije njihove zabrinutosti i/ili nedostatka interesa za igru s djetetom. to be analysed. This is because, even nowadays, the necessary competencies for using digital technology are not being developed during the initial education of educators, and later on, during further professional training. Based on the results of this study, hypothesis H3 was accepted and generational differences are recognised between younger educators with fewer years of work experience, who grew up with new technology, and senior educators with greater number of years of work experience, whose competencies are affected because they are novices when it comes to using such technology.

\section{CONCLUSION}

The unique cultural, ethnic, and speech aspects within a family community, as well as their moral or rural nature, offer and open various opportunities and challenges for strengthening partnerships. The acts of giving and helping are integral parts of the culture in which cohabitation with others and different persons is interwoven (Ward, 2013); this opens up possibilities for new meetings, sharing ideas, and values, which generate the basic principles of partnership (Jackson and Needham, 2014). In an educational institution, this implies recognising and respecting the needs of the family, the authenticity of parenthood, as well as the importance of nourishing close relationships between parents and children, based on which different forms of support will be created that will eventually contribute to the strengthening of those relationships. The results of the present study show that educators generally assess the quality of partnerships and cooperation with parents during the COVID-19 pandemic as high, and that they are optimistic when it comes to initiating cooperation and strengthening partnerships. They consider themselves competent in building partnerships and relationships with parents of all children, as well as in providing help to parents of children with disabilities in recognising priorities for the further development of their child. Educators with a greater number of years of work experience consider themselves less competent to use digital technology and think that they need more theoretical knowledge and practical experience in that aspect. When we analysed the assessment of the difficulty of online cooperation with parents more thorough- 
Rezultati ovoga istraživanja vrijedan su izvor podataka o mogućnostima unapređivanja inicijalnog obrazovanja, profesionalnog razvoja odgojitelja, ali i poticaj za provedbu daljnjih istraživanja o partnerstvu u vrijeme izvanrednih životnih okolnosti, s ciljem unapređivanja prakse, a time i dobrobiti djece. ly, there was a significant difference between the educators with the lowest and the highest number of years of work experience, where educators with fewer years of work experience could handle cooperation via digital media better. Moreover, it should be noted that the educators who acquired higher professional qualifications considered themselves more competent in using digital technology, and at the same time, they thought that they motivated the parents to work with their child more often in order to prevent their concern and/or lack of interest.

The results of this study are a valuable source of information about the possibilities for improving the initial education of educators and for professional development. These results can also motivate further research on partnerships during out-of-the-ordinary life circumstances, with the purpose of improving inclusive practice and the welfare of children as well. 


\section{REFERENCES}

Curtis, D., Carter, M. (2008) Learning together with young children: A curriculum framework for reflective teachers. St. Paul: Redleaf Press.

Christenson, S., Palan, R., Scullin, S. (2009) Family-school Partnerships: An Essential Component of Student Achievement. Principal Leadership, 9(9), 10-16.

Čudina-Obradović, M., Obradović, J. (2006) Psihologija braka i obitelji. Zagreb: Golden marketing and Tehnička knjiga.

Etički kodeks Odbora za etiku u znanosti i visokom obrazovanju (2006) https://mzo.gov.hr/UserDocsImages/ dokumenti/StrucnaTijela/Eti\%C4\%8Dki\%20kodeks\%20odbora\%20za\%20etiku\%20u\%20znanosti\%20i\%20 visokom\%20obrazovanju.pdf (Accessed: 12 December 2020).

Fantuzzo, J., Gadsden, V., Li, F., Sproul, F., McDermott, P., Hightower, D., Minney, A. (2013) Multiple dimensions of family engagement in early childhood education: Evidence for a short form of the Family Involvement Questionnaire. Early Childhood Research Quarterly, 28(4), 734-742.

Fantuzzo, J., Perry, M.A., Childs, S. (2006) Parent Satisfaction with Educational Experiences scale: A multivariate examination of parent satisfaction with early childhood education programs. Early Childhood Research Quarterly, $21(2), 142-152$.

Gartrell, D. (2012) “Goodest” guidance: Teachers and families together. Young Children, 67(3), 66-68.

Giovacco-Johnson, T. (2009) Portraits of partnership: The hopes and dreams project. Early Childhood Education Journal, 37(2), 127-135.

Igrić, Lj. et al. (2015) Osnove edukacijskog uključivanja. Zagreb: Edukacijsko-rehabilitacijski fakultet Sveučilišta u Zagrebu and Školska knjiga.

Jackson, D., Needham, M. (2014) Engaging with Parents in Early Years Settings. London: SAGE Publications.

Jurčević Lozančić, A., Basta, S., Šerbetar, I. (2019) Teachers' Attitudes Towards Collaboration with Parents: Development and Evaluation of the Questionnaire. Sodobna pedagogika, 70(136), 4, 136-150.

Jurčević Lozančić, A., Golik Homolak, I. (2020) Preschool teachers' competencies for inclusive practice and partnership with parents - experiences from Croatia. In: Diamond Scientific Publication (Eds.), Proceedings of the 2nd International Conference on New Approaches in Education (pp. 1-11). Oxford, UK.

Kersey, K.C., Masterson, M.L. (2009) Teachers connecting with families - In the best interest of children. Young Children, 64(5), 34-38.

Keyser, J. (2006) From Parents to Partners: Building a Family - Centred Early Childhood Program. Washington: Redleaf Press, NAEYC.

Kudek Mirošević, J., Tot, D., Šamo, R. (2020) Preschool Teachers’ Experiences in Working with Children in an Inclusive Educational Facility. In: Diamond Scientific Publication (Eds.), Proceedings of The 2nd International Conference on New Approaches in Education (pp. 2-23). Oxford, UK.

Ljubetić, M. (2014) Od suradnje do partnerstva obitelji, odgojno-obrazovne ustanove i zajednice. Zagreb: Element.

Milas, G. (2005) Istraživačke metode u psihologiji i drugim društvenim znanostima. Zagreb: Educa.

Morgan, N.S. (2017) Engaging Families in Schools: Practical strategies to improve parental involvement. New York, Oxon: Routledge.

Nenadić Bilan, D. (2014) Društvena potpora roditeljima djece predškolske dobi. Školski vjesnik: časopis za pedagogijsku teoriju i praksu, (1-2),63, 107-117.

Nitecki, E. (2015) Integrated School-Family Partnerships in Preschool: Building Quality Involvement through Multidimensional Relationships. School Community Journal, 25(2), 195-219. 
Powell, D.R., Son, S.H., File, N., San Juan, R.R. (2010) Parent-school relationships and children's academic and social outcomes in public school pre-kindergarten. Journal of School Psychology, 48(4), 269-292.

Powell, G., McCauley, A.W. (2011) Blogging as a way to promote family-professional partnerships. Young Exceptional Children, 15(2), 20-31.

Sammons, P., Toth, K., Sylva, K. (2015) Pre-school and Early Home Learning Effects on A-level Outcomes: Effective Pre-school, Primary and Secondary Education Project (EPPSE). Research Report. London: DFE.

Souto-Manning, M., Swick, K. (2006) Teachers' beliefs about parent and family involvement: Rethinking our family involvement paradigm. Early Childhood Education Journal, 34(2), 187-193.

Thompson, J. (2015) Vodič za rad s djecom i učenicima s posebnim odgojno-obrazovnim potrebama. Zagreb: Educa.

Ward, U. (2013) Working with Parents in the Early Years. London: SAGE. 